Marta Werbanowska

\title{
Envoy to the World: Nomadic Cosmopolitanism in Yusef Komunyakaa's The Emperor of Water Clocks
}

A water clock is a contradiction in terms: it evokes the human desire to name, control, and understand, as well as the relentless malleability of the natural world. Another term for water clock, clepsydra, stems from the Greek roots kléptein, which means "to steal, conceal" and hydra, which is a derivative of the word for "water"; therefore, the very origins of the term suggest a somewhat clandestine human intervention in the natural flow of volatile and mercurial matter. The title of Yusef Komunyakaa's latest poetry collection to date, the 2015 The Emperor of Water Clocks, announces a poetic subject that turns this surreptitious activity of time measurement into a project of citizenship-formation, as he takes reign over the paradoxical empire of objects whose successful operation depends on the continued flux of their material, yet whose purpose is to provide some human mastery over the intangible. As the poems collected in the volume suggest, at the dawn of the twenty-first century this delicate condition of blurred boundaries and ambiguous belonging is becoming increasingly real for the globalized world we inhabit. Komunyakaa's cosmopolitan poetic consciousness traverses all kinds of boundaries: geographical and national borders, limitations imposed by the linear flow of time, and perimeters of cultural difference. It searches for truths and ethical parameters whose reach would be universal, but remains open to a multitude of a situated subject's positions, life experiences, and interpretations of what is true. Thus, The Emperor of Water Clocks participates in what may be termed a nomadic cosmopolitan discourse, driven by a neo-humanist ethics of forging cross-cultural and transnational solidarity through an accommodation, rather than erasure, of differences, and a sense of shared responsibility for the world inhabited by all kinds of "others." At the same time, in both furthering and complicating this discourse Komunyakaa's poems advocate for a rhizomatic mode of belongingness and a planetary sense of empathy and responsibility, but do so from a specific perspective that echoes the ideals of global Black solidarity proposed by Black (inter)nationalist and Pan-Africanist philosophies.

In Monique-Adelle Callahan's analysis of Komunyakaa's 2011 collection The Chameleon Couch, she interprets Komunyakaa's poetic project as one that aims to "illustrate contemporary transformations in our understanding of the relationship between literature, language, and citizenship as both a local and global phenomenon within the context of a growing transnational ethos" (2). Indeed, throughout the four decades of Komunyakaa's poetic oeuvres, his poetic subjects have often spoken from a perspective that is firmly situated in the poet's own identity-Black, male, North American, locally Southern, globally Western, modern, human-and imaginatively 
open to inhabiting a globalized subjectivity shaped by a myriad of transnational factors, be they political, cultural, or simply informed by personal experience of travel. The "transnational ethos" of Komunyakaa's poetry lies precisely in its openness to and explorations of the shifting meanings of citizenship and belonging in the modern world, combined with an acute awareness of the historical and ideological foundations of this "new" world order. As a citizen of the world, Komunyakaa's poetic subject is concerned with the cross-currents of global cultural exchange, the continued prevalence of totalitarian and militarized power structures around the globe, as well as with the role of cultural and historical memory in the forging of a community that is both transnational and rooted. Privileged with the freedom of geographical and intellectual movement, this cosmopolitan subject continuously traverses the boundaries of time and space, yet often "perches" in specific social, historical, and territorial locations to examine how the particular is always immersed in, and in turn affects, the universal. Restless between here and there, now and then, the local and the global, the personal and the universal, this subject is, in Komunyakaa's own words, always at the crossroads: a "real place between imaginary places-points of departure and arrival ... a junction between the individual and the world" ("Crossroads” 5).

Komunyakaa's poetic subject at the crossroads is endowed with what the philosopher Rosi Braidotti, following Gilles Deleuze, refers to as the consciousness of a nomadic subject. In Braidotti's take, the nomadic consciousness:

is akin to what Foucault called countermemory, it is a form of resisting assimilation or homologation into dominant ways of representing the self. ... The nomadic style is about transitions and passages without predetermined destinations or lost homelands. The nomad's relationship to the earth is one of transitory attachment and cyclical frequentation: the antithesis of the farmer, the nomad gathers, reaps, and exchanges, but does not exploit. (Nomadic Subjects 60)

A nomadic subject is, therefore, a political and ethical instance that, on the one hand, holds the dominant (for example, national) narrative-makers accountable for their misrepresentations of both their subjects and their "others," and that feels at home while being "lost," or not fixedly aligned with any particular location or teleology, on the other. Moreover, the nomad comes to being through a "subjectivity that is relational and outside-directed": she can only identify herself in relation to other subjects and the environment she currently finds herself in (Braidotti, "Becoming-world" 16). Rather than making the nomad a highly individualized subject, the lack of a permanently affixed sense of locatedness, or national or group allegiance fosters a continuous project of forging new, contingent and flexible relationships with its others, and thus requires from such subject a sense of ethical accountability for humanity at large, and of belongingness at a cosmic, in addition to individual or local, level. Instead of following capitalist power dynamics of domination and exploitation, which might easily be applied to such contingent forms of citizenship, the nomadic subject assumes an ethical responsibility for all the others she establishes relations 
with. Her conscious detachment from the national, ethnic, and other universalizing forms of belonging continuously places such subject in the position of a stranger, which Paul Gilroy identifies as "an invaluable ... opportunity to know the world better and to experience it in more complex and satisfying forms" (70). Indeed, for Braidotti, the nomadic "vision of the subject as a time continuum and a collective assemblage implies a double commitment, on the one hand to processes of change, and on the other to a strong sense of community-of 'our' being in this together" ("Becomingworld" 19, italics in original). To the nomadic subject, the sense of a common dwelling poses an ethical imperative of solidarity with all other members of this cosmic "household" and requires a practical strategy of adopting an identity that is always in process, flexibly adjusting to the needs and realities of the ever-changing circumstances. At the same time, mindful of her inevitable materiality, the nomadic subject always speaks from an "embedded and embodied perspective": while her locatedness may not be permanent, the physical environment-human and non-human alikealways shapes the nomad in her current iteration ("Becoming-world" 16).

Given her sense of interconnectedness with the entire world, the nomadic subject is, logically, also a cosmopolitan one, although not in the liberal-individualist meaning of the term. In their introduction to the volume, the editors of After Cosmopolitanism lay down a distinction between "the universalistic, rationalist Neo-Kantian transcendental cosmopolitan models ... and the multi-faceted, affective cosmopolitics of embodied subjectivities grounded in diversity and radical relationality" (2). While the former envisions a cosmopolitan ideal as a collectivity of individuals, all guided by the same "universal" moral values and epistemological certainties, the latter perspective understands cosmopolitanism as a lived practice that takes into account and accommodates the cultural, moral, and political differences between its singular participants. This nomadic mode of cosmopolitanism is closer to what Paul Gilroy calls "vital planetary humanism," or a way of thinking about global conviviality that goes "beyond the issue of tolerance into a more active engagement with the irreducible value of diversity within sameness" $(79,67)$. A similar ethics is also found in Isabelle Stengers' idea of cosmopolitics as a pragmatic process that "has meaning only in concrete situations where practitioners operate" and, contrary to the effectively totalizing Kantian ideal of Eurocentric universalism, delays the creation of a utopian common world by including all standpoints and inviting all actors of the global stage to take part in a difficult, perhaps never-ending, consultation during which a multitude of perspectives activates "a thinking that belongs to no one, in which no one is right" (994, 1001). Although impossibly idealist given the scale of contemporary international politics, cosmopolitics can be thought of as an ethical stance on the individual level. For the nomadic subject, a cosmopolitical consciousness leads to the practice of nomadic citizenship, which Eugene Holland defines as "a sense of belonging and commitment to human community that cosmopolitanism requires," which is detached "from the bounded territory of the nation-state" (152). As these theories illustrate, the cosmopolitan nomadic subject is full of contradictions: at one and the same time 
rooted and migratory; locally situated yet universally-oriented; singular but defined by her relations with a multitude of others; working towards an aim that is continually practiced yet never quite fully realized. Refusal to resolve these contradictions, openness to indeterminacy and difference, and an awareness of the situated yet flexible nature of her own subject position constitute the ethical and political markers of nomadic cosmopolitanism.

In Komunyakaa's poetry, the ethical and political aspects of nomadic cosmopolitanism are implemented in the realm of aesthetics. Echoing Stengers's assertion of polyvocal dissent as a necessary ingredient of cosmopolitical practice, and Braidotti's insistence on the never-finished nature of the nomadic subject, Komunyakaa describes poetry as "a chorus of diversions and chance connections" that "connects us to lyrical tension that has everything to do with discovery and the act of becoming” ("How Poetry Helps" 22, italics in original). This open-ended quality of his work has been observed by several critics. Aracelis Girmay has traced the presence of the figure of Legba-the African god of crossroads and an interpreter between the human and the divine-as a guiding impulse in his poetry and a lesson in "how valuable an understanding of plurality (an ability to straddle worlds!) is in the pursuit of freedom" and empathy (56). Michael C. Dowdy has characterized Komunyakaa's poems as at once creative and political acts that envision a transcendence of the "culturally inscribed forces that constitute difference as conflict in American society" and an establishment of "meaningful self/other relationships" in spite of the country's dominant nationalist impulses (813). And Angela M. Salas has argued for the "universal humanism" and the empathetic versatility of Komunyakaa's poetic subjects, who can "function imaginatively from many different positions" (36). The perspective of nomadic cosmopolitanism, however, reveals his poems as participants in a neo-humanist, rather than "universal humanist," discourse that produces "inclusive alternatives-locations and figurations-that enlarge and go beyond humanist individualism” (Braidotti, “Becoming-world” 18). Inspired as much by Africanesque and African diasporic traditions as by the Western literary canon, rooted in the African American tradition of double consciousness, Komunyakaa's work displays skepticism toward the totalizing discourse of Western humanism. At the same time it does not propose to replace that humanism with a nihilistic or anti-humanist stance, but rather with a neo-humanist sensibility that realizes the situatedness of all truths and the inevitability of conflicting opinions yet recognizes instances of pan-human solidarity as little miracles of shared humanity.

Komunyakaa's poetic subject, endowed with overtly cosmopolitan ways of thinking about belonging and relationality, retains elements of Black nationalism by seeing political and cultural Black solidarity as a mode of organization against the dominant Eurocentric narratives (including the Kantian cosmopolitan ideal). As Tommie Shelby observes in We Who are Dark: The Philosophical Foundations of Black Solidarity, "black political solidarity has come to be associated with black nationalism" (4)-a correlation which, at first, seems antithetical to the cosmopolitan ideals of unbound plan- 
etary belonging and transnational citizenship. Yet the founding principles of Black nationalism have always been transnational and planetary, as the overarching goal of most Black nationalist movements and philosophies is the liberation and empowerment of oppressed and disprivileged peoples globally. From W.E.B. Du Bois and Marcus Garvey to Franz Fanon and the Black Power organizations of the 1960s and 1970s, the most prominent proponents of Black nationalism have always been suspicious of the possibility of an effective "state-sponsored amelioration" of the problems caused by racism, and instead sought solutions to race-related oppression and dispossession "within global black networks, consciousness, and demands" (West and Martin 27). Moreover, the very category of "Blackness" adopted by many of these thinkers was quite flexible and inclusive, often accommodating of difference rather than imposing an imaginary unity, and expanding beyond racial identification to shared experiences of "non-whiteness" as an absence of certain economic and political privileges. From Du Bois's assertion that, while he feels "fanatically a Negro," blackness to him means "a greater, broader sense of humanity and world-fellowship" (16) to Huey Newton's political philosophy of revolutionary intercommunalism and Malcolm X's distinction between civil rights, or asking "Uncle Sam to treat you right," and the God-given human rights that are supposedly "recognized by all nations of this Earth" (35), the history of Black nationalism has largely been at the same time one of internationalism. In the words of Gilroy, since these thinkers and activists understood their position "in planetary terms that confound conventional distinctions between nationalism and cosmopolitanism," it is in the history of Black political culture that one may begin looking for modes of cosmopolitanism that, instead of offering "one more imperialistic particularism dressed up in seductive universal garb," advocate for genuinely ethical and egalitarian social relations across the planet $(57,4)$. Indeed, in its linking of local action and global goals, its focus on embodiment and materiality as crucial elements of one's social existence, and the "double commitment" to political change and communal belonging advocated by Braidotti, much of Black (inter) nationalist thought precedes the cosmopolitical and nomadic cosmopolitan ideals of transnational solidarity in difference and an ethically inclusive communal praxis. The most obviously political poems in The Emperor of Water Clocks clearly echo the "oppression-centered conception of black solidarity" espoused by Black nationalism (Shelby 4). Thus, while the currently circulating theories of nomadic cosmopolitanism merely imply the racial dimension of pan-human social justice, Komunyakaa's poetry inscribes it in the forefront of its cosmopolitan discourse, highlighting the historical significance of race as an othering device in the processes of nation-building, imperialist and capitalist expansion, and citizenship-formation.

An example of a nomadic encounter that is at once cosmopolitan and Afrocentric can be found in perhaps the most reprinted poem from The Emperor of Water Clocks, “The Day I Saw Barack Obama Reading Derek Walcott's Collected Poems.” Like a jazz composition, the poem riffs on a 2009 photograph of Obama with Walcott's collection in hand, yet changes and adds the setting and details of the original picture at 
its improvisatory will. It uses the image's political and poetic symbolism as a starting point for ruminations on the significance of this scene on a national and diasporic scale, as well as on an intimate level for the speaker-who can here be identified with Komunyakaa himself-as an African American man and poet. As the poetic voice follows the US President reading the St. Lucian poet's work "in the official November snow \& sleet / falling on the granite pose of Lincoln” (84), he ponders Obama's motivation for this choice of reading:

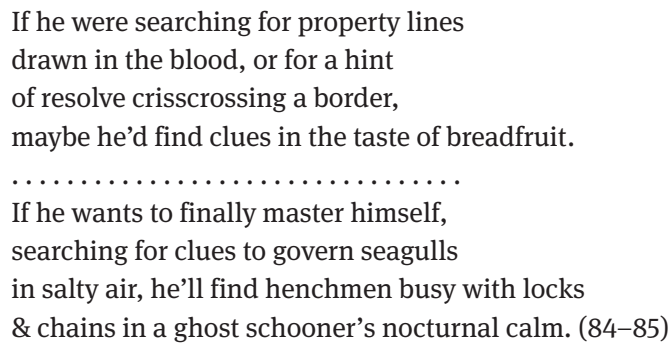

Throughout the poem, the speaker's speculations about the President's psyche are intertwined with references to individual poems by Walcott as well as to his famously syncretic style, one that signifies the aesthetic of "cosmopolitan modernism by representing how the Caribbean experience has been shaped by the myths and histories of Europe, Africa, and the New World" but also inflects Western poetic forms with Caribbean rhythms and realities (Pollard 198). The questions which Obama supposedly asks of Walcott's poetry are about the assertion of a modern African American, or more broadly diasporic Black, identity: how does a Black subject "master himself" as an active agent in the contemporary US, a space historically marked by the experiences of uprootedness, terror, and oppression? The speaker is at once skeptical of the book as a source of answers (an experience of migrants "crisscrossing a border" may perhaps only be understood by "the taste of breadfruit," an organic familiarity with their lived realities and cultural background), and confident in Walcott's futuristic vision as a guideline for (African) American politics: since the poet “won't speak / of milk \& honey, but of looking ahead / beyond pillars of salt raised in a dream" (85), his presidential reader may, too, realize the dangers of excessive dwelling in the North American and transnational past or idealizing the present as utopia incarnate. This orientation toward the future, however, should not mean an erasure of the continued legacy of America's violent history of "chains in a ghost schooner's nocturnal calm" (Emperor 85), but rather a creative reexamination of the "bloodstained workings of racism ... to yield lessons that could be applied more generally, in the demanding contemporary settings of multicultural social relations" (Gilroy 4). Walcott's poetics, at once sharply attuned to the still lingering consequences of the transatlantic slave trade and culturally omnivorous in its claiming of the legacies of Europe, Africa, and Asia, transforms these histories into a specifically New World politics and aesthetics, 
thus offering a blueprint for the forging of a cosmopolitan American in general, and a cosmopolitan Black American subject in particular.

The cosmopolitan Black subject in the poem avoids the risk of adopting an elitist, naive way of thinking about the global North American future as an ahistorical, "postracial” ideal by instead adopting a nomadic perspective which, to quote Braidotti, "accounts for one's locations in terms both of space (geo-political or ecological dimension) and time (historical and genealogical dimension)" ("Becoming-world" 16). This happens not only at the collective level of coming to terms with the historical lessons of racism and racialism as mentioned by Gilroy, but also at the individual level of viscerally experiencing history, place, and culture with one's own body. This embodied and embedded nature of cosmopolitanism becomes clear with the poem's vision of a metamorphosis of Walcott's Collected Poems into a fruit:

\footnotetext{
Now, he looks as if he wants to eat words, their sweet, intoxicating flavor. Banana leaf \& animal, being \& nonbeing. In fact, craving wisdom, he bites into memory. (85)
}

The book-fruit nourishes its reader both metaphorically and literally, offering a reassuring sense of rootedness. Komunyakaa's invention of "November snow" and the "granite pose of Lincoln"-elements absent from the original photograph-may be his way of signaling the cultural and historical whiteness of the White House (a location never explicitly set, but strongly suggested by the poem's imagery) and Wall Street, and thus highlighting the status of Obama as an outsider to the predominantly white Anglo-Saxon milieu of US politics and finance. Counteracting this overwhelming whiteness, the diasporic Black signifiers he finds in the book-from tropical fruit and the climate of "St. Lucia's light" to the reminder that the pyramid image on US currency is, after all, "a sign borrowed from Egypt” (84)-serve as indicators of his belonging to a community much bigger than the US, a pan-humanity of the Black diaspora worldwide. Importantly, just as the poem's Obama finds comfort in Walcott's nourishing words, its speaker reads the scene he witnesses for its reassuring significance for himself. If we conflate the poem's speaker with Komunyakaa, the monumental importance of this scene for its observer becomes clear: for a Black man with Trinidadian roots born in Jim Crow Louisiana, watching as the Black "President of the United States of America / thumbs the pages" (86) of a book of poems by a Black Caribbean Nobel Prize winner is a clear illustration of a vast sociocultural change taking over the world, a change that reinscribes him into the spaces of political power and institutional recognition from which Black people have been historically excluded on a global scale. Thus, for the speaker the sense of Black cosmopolitanism channeled in the poem is not an abstract ideal but a material sensation; the poem's three personae become embodied sites of the global political and cultural transformations symbolized by Obama's presidential function and Walcott's literary status. 
The choice of Obama and Walcott as its main figures makes the poem resonate on multiple levels, as it captures the moment of Black achievement that is at once individual, national, and cosmopolitan, and bridges the gap between these seemingly mutually exclusive concepts. Komunyakaa and Walcott, as Daniel Cross Turner aptly observes, can be seen as each other's doubles in the literary world as "two of the most highly decorated and significant contemporary Black Anglophone poets," both recognized for the transnational qualities of their poetry and its hybrid use of Western and Africanesque "mythopoetic traditions" (54). Walcott's success is thus, by analogy, also Komunyakaa's validation as a Black poet. The iconicity of Obama as an embodiment of "a national transformation inaugurated ... by the election of an African American to the most powerful political office in the world" embeds the poem in the mainstream cosmopolitan discourse of "the United States in terms of a cosmopolitan democracy-as a teeming diversity of people drawn from various countries who had joined together in a single union" (Selzer 25, 29, italics in original). While Obama's presidential career constituted a milestone in the racially-troubled history of the United States, his personal history and transnational ancestry also highlighted the rhizomatic, cosmopolitan lineage of the nation. The key image of the poemthat of the Black President of the United States reading a book by a Caribbean poet in Washington, DC, while observed by an African American poet from the Southevokes a sense of cosmopolitan cultural exchange, trans-regional and transnational movement, and global Black diasporic solidarity at a transitional moment in history which, as this scene optimistically suggests, promises to foster a model of citizenship that is both locally situated and open to translocal interrelations.

While "The Day I Saw Barack Obama ... " channels a sense of faith in the nationstate as an institution able to embrace cosmopolitan modes of coexisting, other poems in The Emperor of Water Clocks are more skeptical about the very possibility of the state's capabilities to act as an agent of positive change. By celebrating the individual achievements of Black subjects in the worlds of US (inter)national politics and institutionalized literature, the above-discussed poem advocates an ideological expansion, rather than eradication or transcendence, of the nation-state: the inscription of Black agency into the structures of political and ideological citizenship-formation is presented as a success by itself, and as a harbinger of a more cosmopolitan nationstate whose porous boundaries can finally admit difference and otherness as valid and successful modes of national belonging. However, in poems such as "Envoy to Palestine” and "Ghazal, after Ferguson," this Afrocentric yet still relatively conservative vision of cosmopolitanism gives way to a more radical understanding of nomadic citizenship as an alternative to the nation-state "and all the exclusions and proclivity to violence that state-citizenship entails” (Holland 152). Echoing the Black (inter) nationalist critique of global Western imperialism and state-sanctioned racism within the United States respectively, these poems reject the possibility of forging "national solutions to black international problems" (West and Martin 25) and instead advocate for a transnational and transcultural solidarity of the oppressed the either bypasses 
or transcends the institutionalized workings of the state. Thus, while "The Day I Saw Barack Obama ..." celebrates at least a partial achievement of the cosmopolitan ideal, the two poems discussed in the remaining sections of this chapter conceive of cosmopolitanism as neither an "established fact, nor a historical tendency or telos," but rather as "an act of social engagement and an ethical commitment ... a possibility" to which the cosmopolitical praxis aspires (Holland 156).

One vision of cosmopolitical solidarity across and despite the boundaries and limitations of nation-states and their capitalist-imperialist modes of global expansion is presented in "Envoy to Palestine." Tracing a historical continuum of settler colonialism from the European invasion of North America to the Israeli occupation of Palestine, the poem opens with an initially unidentified speaker's visit to the grave of Mahmoud Darwish, hailed as the national Palestinian poet, in the city of Ramallah. The speaker's mode of arrival appears both mythical and clandestine, as he finds himself "lucky to have the shadow of a coat" as a "borrowed line transport[s] [him] beneath / a Babylonian moon" (92)-it is never clear whether his presence in the Middle East is an embodied act of trespassing the national borders or merely a journey made within his imagination, a mental travel along a "borrowed line" of a poem. While his actual location remains undisclosed throughout the lyric, the speaker's identity is eventually revealed as he reaches out to his Palestinian addressees in a gesture of trans-ethnic solidarity:

I know a prison of sunlight on the skin.

The land I come from they also dreamt

before they arrived in towering ships

battered by the hard Atlantic winds. (92)

The speaker further identifies himself as a "runagate / redskin, a noble savage, still Lakota” (92). His self-proclaimed status as an envoy is thus paradoxical: he represents a state that does not exist, a nation decimated centuries ago by European settler colonialism and psychologically as well as politically damaged by the history of Anglo-Saxon occupation which has reduced him to a "reprobate whose inheritance / is no more than a swig of firewater" (93). Like his Palestinian hosts, he is a refugee in his own land and a racialized other (a "noble savage" whose complexion is his "prison"). The bond that connects him to the Palestinians is their shared experience of oppression and forced participation in the transhistorical, transcontinental systems of domination.

While Braidotti posits that such "negative bonding of shared vulnerability is not enough to create alternative values" ("Becoming-world” 11), Black (inter)nationalist thought tends to see the shared awareness of exposure to the negative consequences of imperialism and globalization as the first step towards cosmopolitical action. In her discussion of the ideological evolution of Huey Newton's thought from Black nationalism to intercommunalism, Robyn Spencer traces the Black Panther Party's gradual expansion of the "internal colonialism thesis, the idea that African Ameri- 
cans constituted a 'nation within a nation' or an 'internal colony' within the United States," into an understanding of the world as "divided into oppressed and liberated communities, linked by common causes that united them across national boundaries against a common enemy: the United States empire” (223). This version of Black internationalism, in which the shared experience of political and economic oppression-rather than racial or cultural identification-becomes the dominant factor in the forging of a global solidarity, paves the way for a cosmopolitical understanding of difference and singularity as preconditions of, rather than impediments to, the formation of an allegiance. What the Lakota speaker of Komunyakaa's poem and his Palestinian addressees have in common is not a shared racial or cultural identity, but the lived experience of being oppressed and violently "othered" by the forces of imperialism, be they the European invasion on North America or the Israeli occupation of the West Bank. Importantly, the speaker does not attempt to erase or ignore the historical and geographical situatedness of their respective conditions, and is able to, at one and the same time, remain rooted in his specific environment of the "wildflowers, all the grasses / \& insects singing to [him]" and empathically situate himself within the "dried-up riverbed / \& extinct animals" of the Middle East (Emperor 92-3). As a rhizomatically rooted subject, Komunyakaa's envoy is defined not by absence of attachment but by a multitude of relations across various groups and places; he is rooted in "the dust of restless plains" of North America but connects with the inhabitants of the "grassy hill / in Ramallah" through a shared experience of forced uprootedness that stems from warfare, invasion, and territorial occupation (Emperor 92). Thus, he establishes between himself and his addressees a sense of belonging to a community that is bound not by its unified identity, but by a shared condition of vulnerability which he sees as the basis for global solidarity and, perhaps, a mobilizing force for joint resistance.

Although the envoy's message is directed specifically to the people of Palestine, the poem as a material, printed artifact-not unlike Walcott's Collected Poemsreaches a wider, possibly transnational, public of readers, acting as a call to instill in them a sense of belonging to a shared community that faces the global threats of imperialism, neocolonial violence, and international warfare. The final lines of the poem reveal this faith of speaker-envoy and author-poet, now merged in the poetic enterprise, as an instance of cosmopolitics:

... I hear Chief Standing Bear

saying to Judge Dundy, "I am a man,"

\& now I know why I'd rather die a poet

than a warrior, tattoo \& tomahawk. (93)

The decision in the 1879 case of Standing Bear v. Crook, in which Judge Dundy "concluded that Indians have the same rights under the law as whites," has been referred to as the "first significant civil rights case" in the US (Nagle 456). Komunyakaa's mention of Standing Bear's speech, in which the Ponca Chief advocated for the subordination 
of ethnic and racial differences to what he described as a universality of the human condition and thus human rights, serves a twofold, quite paradoxical, purpose: it is a reminder of the power of words to conjure reality, and of their helplessness in the face of brutal power. While Standing Bear's evocation of the human rights' discourse led to a legal recognition of Native Americans as subjects endowed with such rights, history has proven that victory to have been merely formal: the population, virtually powerless from the political and economic standpoints, is still forced to live on the margins of US society, on the invader's terms, which have never been consulted with them. In this somewhat self-referential gesture, the poem ponders its own efficacy as a political tool: its eponymous envoy is too aware of the history of "broken treaties \& smallpox, the irony of barbed wire" (93) to believe in the power of language, speech, and debate as ultimate problem-solvers; and yet, despite these brutal lessons of history, the speaker still declares he'd "rather die a poet."

The acutely self-aware irony of these closing verses reveals the contradiction inherent in the cosmopolitical proposal: while its practical purpose is that of debating solutions, its ethical imperative is to keep the power to execute such possible solutions from any individual or group. The speaker's cosmopolitics is thus a consciously idiotic project in the Deleuzian understanding of the term. In the words of Stengers, the idiot is a presence that “demands we slow down, that we don't consider ourselves authorized to believe we possess the meaning of what we know" (995). While the project of nomadic cosmopolitics may be idiotic in its idealism and deliberate indeterminacy, it is precisely this idiocy that makes it ethical, as it dissolves the concept of power over others and replaces it with endless relationality instead. In the face of the inevitability of death-the poem opens, after all, with the speaker's visit to another poet's grave-Komunyakaa's idiot-poet-nomad chooses a life of compassion and coexistence over the aggressive, objectifying, and dominating globalizing mode of nation-state cosmopolitanism that had led to the genocides of the Native American and Palestinian populations.

As postulated by Stengers, one aspect "of the cosmopolitical proposal is ... to accentuate our own rather frightening particularity among the people of the world" (999). Transnational consciousness of our entanglement in globally-reaching interrelations is only one element of cosmopolitanism, the other being an awareness of and response to our geographical and temporal situatedness-and the cosmopolitan nomadic subject, like Komunyakaa's shape-changing poet or the divine Legba, lives at the ever-shifting crossroads of these two routes. From this position, the nomadic subject engages in the ambiguous process of what Braidotti refers to as "becoming-world," or understanding one's actual situated location as at once the starting point in the search of broader truths and a particularized experience on its own terms.

Similarly, in "Ghazal, after Ferguson" Komunyakaa addresses the historical and cultural specificity of the African American experience of state-sanctioned violence and dispossession through an aesthetic that situates it within a global context without 
de-exceptionalizing it. Along with the title, the opening couplet of the poem establishes the Middle-Eastern poetic form of ghazal and the black lexicon of hip-hop as its main stylistic frameworks: "Somebody go \& ask Biggie to orate / what's going down in the streets” (96). The speaker's impossible plea for the dead rapper's presence as an urban griot who could narrate the events, and thus help the people make sense of their situation, evokes the sense of confusion, disorganization, and voicelessness most likely experienced by the protesters of Michael Brown's fatal shooting by police officer Darren Wilson in Ferguson, Missouri in the summer of 2014. The poem's structure both amplifies this sense of fragmentation and uncertainty, chaotic "motion \& relativity in the streets" of a city in the midst of an uprising (Emperor 97), andthrough the poet's manipulation of the self-imposed limitations of ghazal-performs a neo-humanist search for connections and unity among the unrest. As K. C. Kanda explains, the ghazal is a disjunctive poetic form in which "[e]ach couplet is a selfsufficient unit, detachable and quotable, generally containing the complete expression of an idea" (qtd. in Caplan 119). However, in Komunyakaa's poem some of the couplets break this fundamental rule by introducing images that continue throughout the neighboring couplets:

\footnotetext{
If you're holding the hand lightning strikes

juice will light you up miles for the streets

where an electric chair surge dims

all the county lights beyond the streets. (96-97)
}

By juxtaposing an image of the breakdancing move in which the dancers, holding hands, simulate an electric current flowing through their bodies with that of an execution by electrocution, the poem simultaneously evokes the community-building function of Black urban culture and the state's lethal interventions that disrupt this community. Evoking the Black nationalist trope of understanding the African American population as a "nation within a nation," these contrasting images of electricity as a both animating and deadly force reflect the ongoing struggle between the statesanctioned attempts at eliminating Black culture and this culture's powerful, grassroots resistance that can only be achieved through solidarity-here, literally embodied in the image of the protesters holding hands.

Through this structural play between union and disjunction, between a transnationally "imported" poetic form and the endemically US hip-hop referents, the poem performs two related moves: first, it globalizes the uprising in Ferguson while underscoring the specificity of anti-Black violence in the United States, and second, it searches for a sense of wholeness and order among the brutal chaos of the warlike reality of the riots. Full of paradoxes, the poem at one and the same time expresses the need for the uprising as a venue for expressing collective anguish and disclosing the unethical practices of the law enforcement ("Take back the night. Take killjoy's / cameras \& microphones to the streets” [96]), and recognizes the futility of such efforts: 
even though the protesters "hope for a bypass beyond the streets" (96), or for their grievances to be heard and acknowledged by the criminal justice system as well as the wider public, the poem's structural repetition of the word "streets" at the end of every couplet suggests a never-ending cycle of urban disenfranchisement and protests that do not lead to any substantial change in the ways the law enforcement and the legal system operate. Modern technology, too, is presented as both a means of disseminating news about Ferguson's local events globally and a failed promise of justice: while the tweets that document the unrest stay "lockstep in the frontal lobe" of Internet users worldwide, the "echo chamber of the streets" locks the voices of the protesters into perpetual self-repetition, exposing the self-enclosed nature of social media activism (96). The poem does not lay claim to any immediate solutions to the ongoing crisis either, and its closing lines offer merely a somewhat cryptic rumination on the role of the poet amidst the unrest: "Yusef, this morning proves a crow / the only truth serum in the street" (97).

From the streets, the speaker-now clearly identified with the poet himself-turns inwards, reminding himself of the poet's ethical responsibility as the "witness, protester, and contester" of reality (Callahan 3). With no contextual information to help determine its meaning, the "crow" that is the only promise of "truth in the street" remains radically open to interpretation. It can refer to nearly anything from a grim vision of the carrion-eating bird emerging as the only winner in the aftermath of the bloody man-made conflict to African American pride in one's cultural heritage that originated from situations of state-sanctioned dispossession (or "crowing" about the successful griots of social dissent, such as The Notorious B.I.G. and Grandmaster Flash, referenced in the poem); or the trickster figure of the crow as one who outsmarts his more powerful opponents. As Trudier Harris observes in her reading of Komunyakaa's Vietnam poems, in "a poetry that focuses on violence and violation, the transcendent beauty of creation is our most lingering solace" (114)-when no immediate solutions may be offered, the chaos-organizing function of the poetic craft brings at least a degree of consolation.

However, the formal and aesthetic choices made by the poet in "Ghazal, after Ferguson" imply that this somewhat escapist search for artistic beauty instead of situated action may not be the sole function of this poem. The choice of ghazal as the lyrical structure (and, arguably the poem's referencing of hip-hop's diasporic roots through its evocation of the Barbados-born and Bronx-raised rapper Grandmaster Flash) points to a kind of discursive cosmopolitanism, or what Malin Pereira refers to as a "cosmopolitan sensibility of movement around the globe, borrowing from whatever cultural materials are necessary to say what you have to say" (57). Unlike an act of cultural appropriation, where a cultural artifact is reified in purely aestheticized terms, this cross-cultural borrowing in Komunyakaa's poem points to an actual potential for the forging of a transnational, cosmopolitan consciousness as the beginning of an "organic solidarity emerg[ing] from the ground up between communities bearing the brunt of state repression” (Bailey 1019). As Kristian Davis Bailey observes, what he terms the 
"Ferguson-Gaza moment"-the summer when the Ferguson uprising coincided with "Israel's fifty-day war on the Gaza Strip," causing protesters across the United States to raise the chant of "from Ferguson to Palestine, occupation is a crime"-led to a "resurgence of Black internationalism in the contemporary era" that strongly echoed the Black Panther Party's insistence on the connections between US imperialist endeavors abroad and anti-Black police brutality at home (1017-1018). In this context, the poet's use of a traditionally Middle-Eastern form has a broader anti-imperialist resonance, as it makes a connection between various groups of strangers in their own land (from Palestinians in Gaza to the Black population of the US) and offers an alternative mode of citizenship that detaches "social belonging and ethical commitment from the nearmonopoly exercised ... by the state" (Holland 153). Denied the state-sponsored forms of legal and physical protection, the people can exchange their respective cultural capitals, share their experiences of exclusion and oppression, and ultimately forge alternative, transnational coalitions. A nomadic ethics of establishing connections and building solidarity across locally situated yet universally vulnerable subjects may offer a way to replace state-imposed order with an organic cosmos (from the Greek kósmos, meaning "order, form, arrangement") to the polis of Ferguson and its equivalents around the world.

Several of the poems collected in The Emperor of Water Clocks both advocate the ethical ideals of nomadic cosmopolitics and debunk the myth of cosmopolitanism as something that already has, or inevitably must eventually be, achieved. "Envoy to Palestine" and "Ghazal, after Ferguson" are separated by two other poems of global social protest, about the 2012 civil war in Mali and the protests against the 2012 imprisonment of the punk rock group Pussy Riot in Kiev. This section of the volume, particularly focused on dispelling the myth of cosmopolitanism as an achieved ideal, exposes and condemns the violence of global imperialism on both transnational and local levels; thus, these poems participate in cosmopolitics as a practice of thinking through the modes and ways in which an ethically cosmopolitan world can be achieved. Guided by a nomadic type of consciousness that, to quote Braidotti, moves "across established categories and levels of experience: blurring boundaries without burning bridges" (Nomadic Subjects 26), these poems participate in the neo-humanist project of "strategic universalism" by proposing global solidarity of the disprivileged that neither overlooks the exceptionalism of particular experiences and forms of disenfranchisement nor attempts to impose a single, universalist (say, Western humanist) morality for such prospective cosmopolitan community. A truly egalitarian and inclusive cosmopolitanism is an ethical promise and a political possibility, whose realization depends on collective mobilization of the globally oppressed; echoing this legacy of Black internationalist thought, Komunyakaa's poems suggest the adoption of a nomadic subjectivity-at once rhizomatically rooted in one's particular experience and radically open to establishing non-hierarchical relations with all kinds of others-as one way of achieving this ideal. 
In Nomadic Subjects, Braidotti asserts that one of the objectives of nomadic thought is to find "adequate representations for the sort of subjects we are in the process of becoming to compose significant sites for reconfiguring modes of belonging and political practice" (11). In The Emperor of Water Clocks, Komunyakaa offers poetic and philosophical explorations of the ever-changing modes of citizenship, belongingness, identity, and race in the global context of the twenty-first century world, whose inhabitants, for better or worse, are increasingly interconnected and interdependent. The poems collected in his latest volume delve into various, sometimes contradictory, visions and iterations of cosmopolitanism: from its relatively conservative understanding as a multicultural conviviality that is achievable within the boundaries of the nation-state; to the activist vision of transnational solidarity of the oppressed inspired by the Black (inter)nationalist tradition; and from the discursive cosmopolitanism of cultural hybridity to a more embodied and embedded cosmopolitics of ethical responsibility for the Other as a lived practice. All these incarnations of cosmopolitan thought that appear in Komunyakaa's poems are underscored by a nomadic sense of belonging in the world, producing paradoxical poetic subjects that, culturally or geographically, are at once free-floating and rooted, scattered and firmly situated. This nomadic consciousness is reflected in the open-endedness of the poetic form, which invites dialogue rather than imposes meanings; in the rhizomatic locatedness of the verse, which imbues "the experience of being there with experiences of elsewhere" (Paquet 85); and in the lyrics' ethical imperative of the neo-humanist search for truths and meanings that does not strive to impose their universality but recognizes the situatedness of all individual experience. While often politically engaged, the poems in The Emperor of Water Clocks do not offer instant solutions to the problems they examine, but rather participate in a cosmopolitical ritual that "gives no answer as to the decision to take, offers no 'prophetic' revelation" but instead "transforms each protagonist's relations with his or her knowledge, hopes, fears and memories, and allows the whole to generate what each one would have been unable to produce separately" (Stengers 1002). This idealistic vision of ethical global solidarity as a constant conversation may be seen as counterproductive and subject to the same criticism that was directed against the "fundamental and unresolved dilemma" of the Black (inter)nationalist thought of 1960s and 1970s, whose absolute rejection of state power hindered the possibilities of a feasible actualization of their ideals in practice (West and Martin 31). One must remember, however, that The Emperor of Water Clocks is not a political manifesto but a work of poetry, an "idiotic" enterprise that invites the reader to ponder, rather than come to conclusions about, the meanings of race, citizenship, and identity. Like water clocks, Komunyakaa's nomadic poetic rituals allow their readers to "steal" moments-painful as well as beautiful-from contemporary life around the world and reconsider their own role in the cosmos to which they inextricably belong. 


\section{Works Cited}

Bailey, Kristian Davis. "Black-Palestinian Solidarity in the Ferguson-Gaza Era.” American Quarterly, vol. 67, no. 4, Dec. 2015, pp. 1017-1026. Project MUSE, doi.org/10.1353/aq.2015.0060. Accessed 15 Jan. 2018.

Braidotti, Rosi. "Becoming-world." Braidotti et al., pp. 8-27.

---. Nomadic Subjects: Embodiment and Sexual Difference in Contemporary Feminist Theory. Columbia UP, 2011.

Braidotti, Rosi, et al., editors. After Cosmopolitanism. Routledge, 2013.

Callahan, Monique-Adelle. "Poetry and the Ethics of Global Citizenship." CLCWeb: Comparative Literature and Culture, vol. 15, no. 6, 2013, pp. 1-10, docs.lib.purdue.edu/clcweb/vol15/ iss6/8>. Accessed 11 Apr. 2017.

Caplan, David. “ 'In That Thicket of Bitter Roots’: The Ghazal in America.” Virginia Quarterly Review, vol. 80, no. 4, Fall 2004, pp. 115-134. EBSCO, proxyhu.wrlc.org/login?url=http://search.

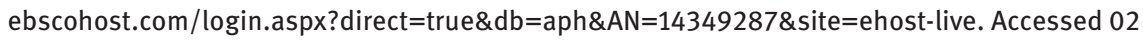
Feb. 2018.

"Clepsydra." Dictionary.com, www.dictionary.com/browse/clepsydra. Accessed 8 Apr. 2017.

"Cosmos." Dictionary.com, www.dictionary.com/browse/cosmos. Accessed 30 Apr. 2017.

Dowdy, Michael C. "Working in the Space of Disaster: Yusef Komunyakaa's Dialogues with America." Callaloo, vol. 28, no. 3, Summer 2005, pp. 812-823. JSTOR, www.jstor.org/stable/3805786. Accessed 26 Jan. 2018.

Du Bois, W.E.B. Darkwater: Voices from within the Veil. Harcourt, Brace and Howe, 1920.

Gilroy, Paul. Postcolonial Melancholia. Columbia UP, 2005.

Girmay, Aracelis. "A-Legba Poetics: Reading Komunyakaa." Black Renaissance, vol. 14, no. 2, Fall 2014, pp. 46-57. ProQuest, search.proquest.com.proxyhu.wrlc.org/docview/1651365193?ac countid=11490. Accessed 15 Jan. 2018.

Harris, Trudier. The Scary Mason-Dixon Line: African American Writers and the South. Louisiana State UP, 2009.

Hass, Robert, et al. “ 'How Poetry Helps People to Live Their Lives': APR's 25th Anniversary Celebration." American Poetry Review, vol. 28, no.5, Sept./Oct. 1999, pp. 21-7. JSTOR, www. jstor.org/stable/27783231. Accessed 15 Jan. 2018.

Holland, Eugene. "Global Cosmopolitanism and Nomadic Citizenship." Braidotti et al., pp. 149-165.

Komunyakaa, Yusef. "Crossroads.” Ploughshares, vol. 23, no. 1, Spring 1997, pp. 5-6. JSTOR, www. jstor.org/stable/40354699. Accessed 02 Feb. 2018.

---. The Emperor of Water Clocks: Poems. Farrar, Straus and Giroux, 2015.

Malcolm X. Malcolm X Speaks: Selected Speeches and Statements. Edited by George Breitman, Grove, 1990.

Nagle, Mary Kathryn. "Standing Bear v. Crook: The Case for Equality Under Waaxe's Law." Creighton Law Review, vol. 45, no. 3, Apr. 2012, pp. 455-502. EBSCO, proxyhu.wrlc.org/login?url=http:// search.ebscohost.com/login.aspx?direct=true $\& d b=a p h \& A N=77504603 \&$ site $=$ ehost-live. Accessed 26 Jan. 2018.

Pereira, Malin. Into a Light Both Brilliant and Unseen: Conversations with Contemporary Black Poets. U of Georgia P, 2010.

Pollard, Charles W. "Traveling with Joyce: Derek Walcott's Discrepant Cosmopolitan Modernism." Twentieth Century Literature, vol. 47, no. 2, Summer 2001, pp. 197-216. JSTOR, www.jstor.org/ stable/827849. Accessed 15 Jan. 2018.

Paquet, Sandra Pouchet. "The Caribbean Writer as Nomadic Subject or Spatial Mobility and the Dynamics of Critical Thought." Journal of West Indian Literature, vol. 18, no. 2, Apr. 2010, pp. 65-94. JSTOR, www.jstor.org/stable/23019918. Accessed 26 Jan. 2018. 
Salas, Angela M. "Race, Human Empathy, and Negative Capability: The Poetry of Yusef Komunyakaa.” College Literature, vol. 30, no. 4, Fall 2003, pp. 32-53. JSTOR, www.jstor.org/ stable/25115154. Accessed 15 Jan. 2018.

Selzer, Linda F. "Barack Obama, the 2008 Presidential Election, and the New Cosmopolitanism: Figuring the Black Body." MELUS, vol. 35, no. 4, Winter 2010, pp. 15-37. JSTOR, www.jstor.org/ stable/25759556. Accessed 02 Feb. 2018.

Shelby, Tommie. We Who Are Dark: The Philosophical Foundations of Black Solidarity. Harvard UP, 2005.

Spencer, Robyn. “Merely One Link in the Worldwide Revolution: Internationalism, State Repression, and the Black Panther Party, 1966-1972." West et al., pp. 215-231.

Stengers, Isabelle. “The Cosmopolitical Proposal.” Translated by Liz Carey-Libbrecht. Making Things Public: Atmospheres of Democracy, edited by Bruno Latour and Peter Weibel, MIT P, 2005, pp. 993-1003.

Turner, Daniel Cross. "Modern Metamorphoses and the Primal Sublime: The Southern/Caribbean Poetry of Yusef Komunyakaa and Derek Walcott." Southern Quarterly, vol. 48, no. 3, Spring 2011, pp. 52-69. EBSCO, proxyhu.wrlc.org/login?url=http://search.ebscohost.com/login. aspx?direct=true\&db=aph\&AN=64156164\&site=ehost-live. Accessed 02 Feb. 2018.

West, Michael O., and William G. Martin. "Contours of the Black International: From Toussaint to Tupac." West et al., pp. 1-44.

West, Michael O., et al., editors. From Toussaint to Tupac: The Black International since the Age of Revolution. U of North Carolina P, 2009. 